ks. Arkadiusz Cygański ${ }^{1}$

Uniwersytet Papieski Jana Pawła II w Krakowie

\title{
Homilia z udziałem dzieci
}

Jezusowe wezwanie: „pozwólcie dzieciom przychodzić do Mnie i nie przeszkadzajcie im" (Łk 18, 16), jest nadal aktualne i zobowiązujące. Jest to wezwanie także wobec homilistów, aby przepowiadając, prowadzili dzieci do przeżycia spotkania z Jezusem w liturgii i przyjęcia Jego nauki na poziomie ich rozwoju osobowego. Przepowiadanie homilijne musi więc z jednej strony respektować naturę liturgii oraz uwzględnić specyfikę zgromadzenia i kontekst przepowiadania. Niniejszy artykuł zamierza wskazać, jak zachować homiletyczną zasadę wierności Bogu i człowiekowi w przepowiadaniu liturgicznym do zgromadzenia, w którym dzieci przeważają lub są po prostu obecne z dorosłymi. Kwestia ta jest wciąż aktualna i delikatna, czy wręcz kontrowersyjna. Zauważa się bowiem przypadki infantylnego traktowania homilii i sprowadzania jej do roli zabawnej i moralizatorskiej pogawędki religijnej w trakcie mszy świętej bądź strofowania dzieci albo ich rodziców za niewłaściwe zachowanie. Wielu homilistów mówiących do dzieci stara się jednak spełniać stawiane homilii wymagania, rozumiejąc, że nie chodzi o homilię dziecinną,

1 Ks. dr Arkadiusz Cygański - kapłan diecezji zielonogórsko-gorzowskiej. Absolwent Uniwersytetu Papieskiego Jana Pawła II w Krakowie i Studium Retoryki Uniwersytetu Jagiellońskiego. Związany z Ruchem Światło-Życie. Zainteresowania: komunikacja homilijna, zwłaszcza dialog. E-mail: xcarek@interia.pl. 
ale skierowaną do dzieci, czy raczej homilię z ich udziałem. Wychodząc naprzeciw tym staraniom, niniejszy artykuł przedstawi dialog jako zasadę i formę przepowiadania homilijnego do dzieci. W Dyrektorium o mszach świętych z udziałem dzieci stwierdzono wprost, że „homilia skierowana do dzieci niekiedy będzie przechodzić w dialog z nimi, chyba że lepiej jest, aby dzieci słuchały w milczeniu" (DMD 48)2. Sam termin „homilia”, wywodzący się od greckiego czasownika homileo, homilein (gr. ó $\mu \imath \lambda \varepsilon \omega$, o $\mu \imath \lambda \varepsilon \imath v)$ wprost wskazuje na przyjazną rozmowę. Według literatury chrześcijańskiej homilia oznacza rodzinną rozmowę, której atmosfera przypomina ojcowskie łamanie chleba z dziećmi ${ }^{3}$. Zagadnienie dialogu w homilii zostanie przedstawione zwłaszcza na gruncie homiletyki formalnej, a pewne jego wątki także w obszarze fundamentalnej i materialnej.

\section{Homilia dialogiem}

Poszukując odpowiedzi na pytanie, jak przepowiadać do dzieci, należy najpierw przypomnieć, że homilia jest częścią liturgii. Podziela ona jej naturę i ma swoje miejsce w jej dialogicznej strukturze ${ }^{4}$. Jest wręcz homogeniczną częścią liturgii słowa. Fakt ten bywa niestety ignorowany i dlatego

2 Kongregacja do spraw Kultu Bożego, Dyrektorium o mszach św. z udziałem dzieci Pueros Baptizatos (01.11. 1973) [dalej: DMD], 48. Późniejsza międzydykasterialna instrukcja Eccelesiae de mysterio z 1997 roku pozwala już na dialog w homilii nie tylko z dziećmi. Instrukcja o niektórych aspektach dotyczących współpracy wiernych świeckich w ministerialnej posłudze kapłanów Ecclesia de Misterium (1997), „Acta Apostolicae Sedis” 89 (1997), 3 § 2 i 3.

Por. E. Sobieraj, Homilia w katolickiej teologii posoborowej, w: Eucharystia $w$ duszpasterstwie, red. A. L. Szafrański, Lublin 1977, s. 217. Źródłosłów grecki podkreśla przede wszystkim sposób i klimat tej rozmowy. Obecne w niej relacje interpersonalne noszą znamiona życzliwego dialogu, którego uczestnicy mówią całą swoją osobą. Por. K. Panuś, Historia kaznodziejstwa, Kraków 2007, s. 22-23.

W starożytności chrześcijańskiej homilia oznaczała rodzinną rozmowę duszpasterza z powierzonym mu ludem w klimacie zaufania lub rozprawę wewnątrz zgromadzenia ludzi. Por. H. Sławiński, Między ciagłościa a zmiana. Teoria homilii w Stanach Zjednoczonych po II soborze watykańskim, Kraków 2008, s. 20-21.

4 Por. D. Grasso, La predicazione alla comunitá cristiana, Roma 1969, s. 42. 
spotykamy obce duchowi liturgii, niemal teatralne występy homilistów przed dziećmi. Tymczasem homilia mszalna, jak podaje Dyrektorium homiletyczne, ma „prostą" i „wymagającą” dynamikę, która wiąże się ściśle $\mathrm{z}$ dynamiką paschalną liturgii ${ }^{5}$. Jest to dynamika dialogiczna, ponieważ dokonuje się w niej zwrot ku Bogu i człowiekowi $i^{6}$. Podobnie jak w całej liturgii, także w homilii przenikają się nurty katabasis i anabasis, gdyż wypowiadają się w niej wobec siebie Bóg i człowiek. Wielu ojców Kościoła kończyło swoje homilie doksologią i słowem „amen”, ponieważ rozumieli, że homilia nie tylko uświęca lud, lecz także wysławia Boga (DH4). W homilii mamy do czynienia z dialogiem egzystencjalnym, w którym Bóg mówi do człowieka poprzez słowa i działanie sakramentalne w obrzędzie, a człowiek odpowiada wiarą, modlitwą, a w dalszej perspektywie życiem inspirowanym słowem Bożym. Bóg wypowiada się wobec człowieka w kontekście jego sytuacji egzystencjalnej, a ten powierza się Bogu w akcie wiary, nadziei i miłości, chociaż może on również odrzucić słowo Boże. Homilia jest więc bardziej dynamicznym wydarzeniem niż statycznym pouczaniem. Realizuje ona spotkanie z Bogiem przez Jezusa Chrystusa w Duchu Świętym we wspólnocie Kościoła. Homilia proklamuje Chrystusa obecnego w liturgii i ożywia relacje między Nim i zgromadzeniem (relacje wertykalne) i między poszczególnymi uczestnikami liturgii (relacje horyzontalne) ${ }^{7}$. Homilia zatem jest aktem dialogu liturgicznego. Papież Benedykt XVI w adhortacji apostolskiej Verbum Domini przypomniał, że homilia jest częścią liturgii i wskazał na organiczny niemal związek słowa i Eucharystii, gdyż słowo „wyjaśnia i oświeca tajemnicę eucharystyczną, a Eucharystia urzeczywistnia słowo" (por. VD 55)․ Mówiąc wręcz o sakramentalności słowa, stwierdził: „Słowo Boże wkracza w czas i przestrzeń, stając się interlokutorem człowieka wezwanego

5 Kongregacja ds. Kultu Bożego i Dyscypliny Sakramentów, Dyrektorium homiletyczne [dalej: DH], 12-15.

6 Por. W. Głowa, Homilia jako forma liturgicznego przepowiadania, „Roczniki Teologiczne” 50 (2003) 8, s. 186-190.

Por. W. Przyczyna, Przepowiadanie w liturgii. Cechy posoborowej homilii, „Ateneum Kapłańskie" 521 (1996), s. 182-183.

8 W adhortacji apostolskiej Sacramentum caritatis Benedykt XVI prosił, by głoszone słowo Boże było ściśle związane z celebracją sakramentalną (SC 46). 
do przyjęcia w wierze Jego daru" (VD 56). Homilia jest pomostem między słowem biblijnym a misterium liturgicznym. Aktualizuje oraz podtrzymuje wiarę i usposabia do jej wyznania, co z kolei jest warunkiem owocnego uczestnictwa w liturgii. Tak rozumiana homilia co prawda nie jest bezwzględnie konieczna dla ważności liturgii, ale bez niej liturgia byłaby niekompletna ${ }^{9}$. Święta Kongregacja Obrzędów w instrukcji Eucharisticum misterium z 1967 roku łączy głoszenie homilii z soborowym wezwaniem do pełnego uczestnictwa wiernych w liturgii (EM 10), gdyż przyczynia się ona do rozpoznania Chrystusa w celebracji, pomaga odpowiedzieć na Jego słowo i obecność pełnym uczestnictwem w liturgii, poczynając od wyznania wiary i modlitwy wiernych, aż do liturgii obrzędu, a potem poprzez nawrócenie i życie chrześcijańskie ${ }^{10}$. Dotyczy to również uczestnictwa dzieci w liturgii, jednakże według ich możliwości percepcyjnych, emocjonalnych i motorycznych. Soborowy postulat pełnego, świadomego i czynnego uczestnictwa w liturgii (partecipatio actuosa) odnosi się do homilii tak jak do innych części liturgii. Należałoby może zatem zaniechać określenia "homilia dla dzieci”, podobnie jak i potocznie używanej nazwy „msza dla dzieci”, na rzecz „homilia w mszy z udziałem dzieci”, analogicznie do określenia "modlitwa eucharystyczna w mszach z udziałem dzieci”. Przyimek „dla” określa bowiem ukierunkowanie czynności przepowiadania i dlatego sugerować może, że to dzieci są celem homilii. Tymczasem są one adresatami, a jako podmiot dialogu homilijnego niejako jej współtwórcami. Lepiej więc byłoby mówić o homilii z udziałem dzieci. Nie jest to tylko gra słów. Niekiedy podczas mszy z udziałem dzieci

9 Por. H. Sławiński, Między ciągłością a zmianą..., dz. cyt., s. 37-39. Związek homilii z liturgią wskazuje Magisterium Kościoła w następujących dokumentach: Nowe ogólne wprowadzenie do mszału rzymskiego (NOWMR 55, 65-66, 213), Wprowadzenie do drugiego wydania lekcjonarza mszalnego (WLM 24-27), Kodeks prawa kanonicznego (KPK kan. 767), Dyrektorium Ecclesiae imago de pastorali ministerio episcoporum z 1973 roku (EI 59). Dyrektorium to nawiązuje do KL 35, gdy inne bazowały na KL 52. Wskazuje, że homilia na podstawie świętego tekstu objaśnia cudowne dzieła Boże, a jej celem jest ożywienie uczestnictwa w liturgii (EI 57, 59). Kongregacja do spraw Kultu Bożego zabroniła rozpoczynania homilii znakiem krzyża czy pozdrowieniem: „niech będzie pochwalony Jezus Chrystus”, które sugerują, jakoby była odrębna liturgią czy dodatkowym elementem. Por. Święta Kongregacja Kultu Bożego, „Notitiae”, Cittá del Vaticano, 3 (1973) 9, s. 178.

10 Por. S. Dyk, Homiliajako integralna część liturgii eucharystycznej, ,Zeszyty Naukowe KUL” 48 (2005) 3/191, s. 62-63. 
zabiegi homilisty, jak i oczekiwania rodziców zmierzają w tym kierunku, aby dzieci zabawić, żeby nie nudziły się one podczas mszy świętej. Tymczasem rodzice powinni w ramach katechumenatu rodzinnego wprowadzać dziecko do modlitwy liturgicznej i poprzez swoje uczestnictwo wdrażać dzieci do udziału w liturgii. Nie chodzi jednak o przesadnie surowe egzekwowanie z góry nakazanych postaw podczas liturgii, które mogłoby zablokować dziecko w kontakcie z Bogiem i wręcz zrazić do liturgii. Należy uwzględniać etapy rozwoju osobowego dziecka także w kontekście jego udziału w liturgii i na każdym z nich angażować się z nim w liturgię tak, aby z czasem coraz świadomiej odczuwało ono, że uczestniczy w niej wspólnie z innymi. Formą udziału w homilii jako akcie liturgicznym może być dialog. Jest on fundamentalną, wewnętrzną zasadą przepowiadania homilijnego, nawet jeśli forma tego przepowiadania pozostanie monologowana. $\mathrm{W}$ dialogu homilijnym bierze się pod uwagę uczestników liturgii oraz ich sposób myślenia, tak w fazie przygotowywania, wygłaszania, jak i ewaluacji przepowiadania po homilii. Dialog jako zasada homilii sprzyja budzeniu i kształtowaniu osobowej wiary słuchaczy, dając im możliwość osobistego ustosunkowania się do prawdy zbawczej. Homiliści i wszyscy odpowiedzialni za inicjację chrześcijańską dzieci powinni zatem przyjąć dialogiczne nastawienie do swoich słuchaczy. Homilista o dialogicznym nastawieniu wcale nie straci autorytetu, ale jako moderator dialogu homilijnego pozostanie skutecznym nauczycielem i mistagogiem, który naucza prawdy i wprowadza we współdziałanie z Chrystusem w liturgii.

W niniejszym opracowaniu dialog będzie rozumiany jako akt komunikacji interpersonalnej, w którym osoby wyrażają się wzajemnie wobec siebie, głównie werbalnie, choć także niewerbalnie, dążąc wspólnie do odkrycia i przyjęcia prawdy oraz nawiązania lub ożywienia relacji osobowych i tworzenia wspólnoty ${ }^{11}$. Uczestnicy dialogu zwracają się do siebie nawzajem w sposób refleksyjny i dobrowolny, aby wyrazić siebie. Zachodzi w nim interakcja i taka komunikacja interpersonalna, że osoby

11 W greckim rdzeniu słowa „dialog” znajduje się wyraz legein, który znaczy „mówić”, ale też „gromadzić”. Por. L. Kuc, Praktyka przepowiadania słowa Bożego. Materiały do nauczania w zakładach teologicznych, t. 2, Warszawa 1973, s. 109-110. 
mówią lub słuchają się w sposób "maksymalizujący to, co osobiste” 12 . W dialogu homilijnym uczestniczą Bóg, homilista i zgromadzenie liturgiczne $\mathrm{z}$ indywidualnymi osobami.

\section{Dialog homilijny}

Bardzo skuteczną formą przekazu dzieciom treści religijnych, jest narracja, zwłaszcza prowadzona dynamicznie, prostym językiem z obrazowymi przykładami. Dzieci włączają się w opowiadanie jako słuchacze i reagują emocjonalnie i somatycznie (mimiką twarzy, spojrzeniami, gestami), fonicznie (dźwiękami zachwytu, westchnieniami) czy werbalnie (słowami). Ponadto ich odpowiedzią na słuchane słowa są obrazy jakie malują w swojej wyobraźni. Te ich specyficzne odpowiedzi na narrację ewangeliczną podczas homilii można włączyć $\mathrm{w}$ proces przepowiadania. Wydaje się więc, że pełniejszą metodą i formą głoszenia homilii jest dialog.

Na gruncie homiletyki formalnej wyróżnia się dwa rodzaje dialogu homilijnego - wirtualny i realny. Dialog wirtualny określa się jako domyślny albo dialog-zasadę ${ }^{13}$. Jest to dialog, w formie monologu, którego wewnętrzna struktura opiera się na interakcji między nadawcą i odbiorcą. Homilista adresuje swoją wypowiedź w taki sposób, że odbiorcy odczuwają, iż realnie współuczestniczą w homilii i ją współtworzą, wewnętrznie dialogują z homilistą ${ }^{14}$. Mówimy wtedy o homilii dialogicznej.

12 J. Stewart, Mosty zamiast murów. Podręcznik komunikacji interpersonalnej, tłum. J. Suchecki i in., Warszawa 2008, s. 49-55. Dialog nie ogranicza się wyłącznie do wymiany zdań, ale absorbuje ontologicznie całą osobę na rzecz drugiej osoby do tego stopnia, że jedna dla drugiej jest darem. Edward Sobieraj stwierdza: „Prawdziwy dialog jest spotkaniem osób. [...] jest relacją interpersonalną, przez którą osoba komunikuje coś innej osobie, będąc jednocześnie zaproszeniem do dania odpowiedzi, do przyjęcia określonej postawy”. E. Sobieraj, Homilia w Katolickiej teologii posoborowej, w: Eucharystia w duszpasterstwie, red. A. L. Szafrański, Lublin 1977, s. 216-217.

13 Por. W. Chaim, Rozmowa w przekazie kaznodziejskim, w: Retoryka na ambonie, red. P. Urbański, Kraków 2003, s. 302.

14 Por. J. Wal, Vademecum dialogu, Kraków 1998, s. 93; J. Wal, Dialog, w: Leksykon teologii pastoralnej, red. R. Kamiński, W. Przygoda, M. Fijałkowski, Lublin [brw], s. 175-181. 
Taki dialog zachodzi na wzór rozmowy rodzinnej, w której nie wszyscy muszą mówić, ale wszyscy odczuwają, że w niej biorą udział.

Dialog wirtualny pojawia się już w fazie przygotowania homilii, gdy homilista, uwzględnia dziecięcy świat uczuć, wyobrażeń, doświadczeń, czy sposób pojmowania przez nich rzeczywistości i szczególne ich potrzeby. Orientując się w ich sytuacji egzystencjalnej, może ją interpretować w świetle słowa Bożego, a z drugiej strony odczytywać tekst święty w kontekście ich przeżyć. Stosując zasadę inkluzji, włącza myśli i doświadczenia słuchaczy do przepowiadania. W ten sposób głoszący nadaje swojej wypowiedzi pożądaną dialogowość, bo odnosi ku sobie nawzajem nadawcę i odbiorcę komunikatu ${ }^{15}$. Dlatego przepowiadający musi wejść w świat dzieci, aby poznać ich perspektywę rzeczywistości i wobec niej odczytać przesłanie Ewangelii. Pomocne do tego mogą być swobodne rozmowy z dziećmi poza liturgią, choćby w czasie katechezy, w gronie rodzinnym, a także analiza różnych ich wypowiedzi i zachowań.

Dialogicznemu przepowiadaniu służą różne zachowania językowe, przeważnie figury retoryczne, jak np. pytania retoryczne, mowomyślenie, apostrofa czy dialogizm. Ważną rolę pełnią również zachowania niewerbalne. Homilista zaznacza swoją relację do treści i autorów potencjalnych wypowiedzi intonacją głosu, mimiką twarzy i gestami. W ten sposób pobudza słuchaczy do reakcji wewnętrznej, a niewykluczone, że i zewnętrznej, w tym także werbalnej. Słuchacze reagują na różne sposoby, np. natężeniem uwagi/wzroku, przytakiwaniem głową, spojrzeniem wyrażającym wątpliwość, znudzonym wyrazem twarzy bądź też czynnościami ubocznymi, jak ziewanie czy rozglądanie się. Słuchacze swoje zainteresowanie wypowiedzią homilisty mogą wyrazić także stopniowaniem milczenia. Umiejętność odczytywania takich reakcji pozwoli homiliście podążać za słuchaczem i dostosowywać przepowiadanie do zdolności percepcyjnych dzieci ${ }^{16}$. Powinien on zatem kształtować w sobie zdolność aktywnego słuchania i obserwacji dzieci. Homilista musi postępować jak przewodnik podczas wycieczki, który co jakiś czas sprawdza, czy podopieczni za nim nadążają, dostosowuje

15 Por. S. Rostworowski. Czy naprawdę kazanie dialogowe?, „Homo Dei” 38 (1969) 3, s. 224.

16 Por. Stanček L., Kňaz rétor, Spišské Podhradie 2001, s. 206-207. 
się do ich możliwości percepcyjnych i pobudza uwagę. Niewykluczone, że pomocne będą w tym pytania do dzieci w celu uzyskania odpowiedzi na temat tego, co do nich powiedział. Ważne są przy tym autentyczność i twórczość głosiciela wobec reakcji dzieci. Wymaga to mowy żywej, która jest wydarzeniem interakcyjnym, nie zaś odgórnie przyjętym schematem zachowania. Przeciwieństwem tego jest stosowany przez niektórych głosicieli monolog rozpisany na role, nazywany tylko dialogiem. W takiej sytuacji homilista zadaje pytania z tezą, a nawet rozpoczyna odpowiedź, bo chce, żeby dzieci jedynie wypowiedziały to, co on myśli. W ten sposób niweluje atmosferę dialogu, gdyż zaprogramowuje odpowiedzi dzieci, ogranicza ich twórcze myślenie i możliwość osobistego przyjęcia treści przepowiadania.

Natomiast dialog realny można inaczej określić jako rzeczywisty i formalny, ponieważ określa on formę przepowiadania. Można też mówić o procesie lub metodzie ${ }^{17}$. Jest to bezpośrednia rozmowa homilisty ze słuchaczami, w której uczestnicy mają szansę dzielenia się myślami na temat czytań biblijnych w kontekście aktualnej liturgii i życia ${ }^{18}$. Dotychczas w polskiej homiletyce zaproponowano różne sposoby stosowania dialogu realnego w homilii. Na uwagę zasługują propozycje Edwarda Sobieraja, Antoniego Lewka, Gerarda Siwka czy Władysława Chaima ${ }^{19}$.

Pierwsza to dialog dwóch osób. Niegdyś prowadziło go dwóch kaznodziejów, czego śladem są pozostałe w niektórych świątyniach dwie ambony. Praktyka ta jest jednak obecnie sprzeczna z obowiązującymi normami

17 Por. W. Chaim, Rozmowa w przekazie kaznodziejskim, dz. cyt., s. 304

18 Por. W. Chaim, Rozmowa w przekazie kaznodziejskim, dz. cyt., s. 311. Nie oznacza to abdykacji przepowiadającego na rzecz wiernych świeckich. Homilista bowiem przewodniczy homilii tak jak celebrans aktom liturgicznym.

19 Por. E. Sobieraj, Homilia $w$ katolickiej teologii posoborowej, w: Eucharystia $w$ duszpasterstwie, red. A. L. Szafrański, Lublin 1977, s. 239-240; por. A. Lewek, Problem dialogu w kaznodziejstwie, „Biblioteka Kaznodziejska” 87 (1971) 2-3, s. 137-139; por. G. Siwek, Dialog w głoszeniu słowa Bożego, „Biblioteka Kaznodziejska” 2/151 (2007) 3-4, s. 11-12; por. W. Chaim, Rozmowa $w$ przekazie kaznodziejskim, dz. cyt. Zostaną tu przywołane tylko takie propozycje dialogu, które odpowiadają komunikacji homilijnej, uwzględniają podmiotowość uczestników i zachodzące między nimi odniesienia osobowe oraz realizują soborowy postulat czynnego uczestnictwa wiernych w liturgii, a przede wszystkim respektują obowiązujące normy liturgiczne. 
liturgicznymi. Zasada uobecniania i reprezentowania Chrystusa w liturgii in persona Christi capitis uwzględnia konkretną osobę jednego szafarza, a nie zespół osób. Ponadto obecnie bardziej przekonująca dla współczesnych byłaby współpraca homilisty z osobą reprezentatywną wobec wspólnoty, uprzednio przygotowaną, która ma kompetencję zawodową bądź osobiste doświadczenie związane z tematem homilii. Może ona pomóc pozostałym słuchaczom lepiej zrozumieć i przyjąć orędzie zbawcze. Wskazane jest, aby taką osobą był rodzic lub rodzice, katecheta bądź ktoś inny kompetentny. Warto zwrócić uwagę, że taka współpraca homilisty z tymi osobami może utrwalać, a nawet podnieść ich autorytet w oczach dzieci. Po drugie wskazuje na łączność przesłania Ewangelii z życiem. Ważne przy tym jest, aby taka osoba uczestniczyła w całej liturgii z dziećmi, a nie tylko była chwilowym gościem.

Druga forma dialogu rzeczywistego w homilii to rozmowa homilisty z uczestnikami liturgii. Mówimy wtedy o homilii zespołowej lub otwartej. Można w niej wyróżnić dwie odmiany dialogu: nauczający i wolny (spontaniczny).

Dialog nauczający polega na tym, że homilista najpierw wprowadza słuchaczy w zagadnienie religijne wynikające ze słowa Bożego, aby zadawali pytania dotyczące słowa Bożego, celebrowanego misterium i sytuacji egzystencjalnej zgromadzenia. Nie może to być jednak zabieg wprowadzający słuchaczy w konsternację, ale mobilizujący do szczerej wypowiedzi. Może on zachęcić do rozmowy prowokacyjnym pytaniem bądź opowiadaniem z życia wziętym, nie zaś wyłącznie bajkowym czy magicznym.

W dialogu wolnym homilista moderuje dialog, a słuchacze zabierają głos spontanicznie. Homilista winien nawet zachęcać słuchaczy do przedstawiania nasuwających się im myśli związanych ze słowem Bożym czy liturgią. W tym celu może przybliżyć się do słuchaczy, a nawet przechadzać się pośród nich. Rodzi się jednak obawa, że na skutek rozdzielenia miejsca odczytywania słowa Bożego od miejsca głoszenia homilii w świadomości lub podświadomości wiernych nastąpi oddzielenie przepowiadania od Ewangelii i liturgii. Z drugiej strony przestrzeń architektoniczna wielu świątyń nie zapewnia homiliście należytej bliskości potrzebnej w dialogu. Pewnym rozwiązaniem byłoby pozostanie 
na ambonie podczas ogłaszania kerygmatu i przekazywania Magisterium Kościoła. Ostateczne rozwiązanie tej kwestii należy pozostawić rozeznaniu homilisty. Decydując się na prowadzenie dialogu wolnego, homilista winien uwzględnić poziom świadomości religijnej i życia duchowego uczestników zgromadzenia oraz ich umiejętności otwartej rozmowy. Dialog spontaniczny w homilii domaga się kompetencji teologicznych i komunikacyjnych, kultury słowa, a nawet poczucia humoru homilisty. Musi on zachować wierność doktrynie Kościoła i jeśli trzeba, taktownie korygować błędy teologiczne. Ma nawet prawo skomentować wypowiedzi w trybie oznajmującym, tak by wykazać ich zgodność lub niezgodność z nauką Kościoła. Nie należy pozostawiać bez korekty błędnych wypowiedzi dzieci o Bogu. Jeżeli zaś trzeba, powinien przerwać wypowiedź nieodpowiednią, a równocześnie uszanować wypowiedzi, które są osobistym wyznaniem.

W dialogu realnym chodzi o wspólne szukanie, odnalezienie i przyjęcie prawdy zbawczej oraz wprowadzenie dzieci w relację osobową z Bogiem. Głównym odpowiedzialnym za przekazanie orędzia zbawczego jest oczywiście przepowiadający. Dorota Sarzyńska, badając dialogowane homilie dla dzieci, wyróżniła w nich trzy strategie nadawcze homilisty ${ }^{20}$. Według pierwszej najpierw prowadzi on dialog ze słuchaczami, a potem wygłasza monolog. W segmencie pierwszym homilista pyta słuchaczy o postaci i sytuacje z wysłuchanych perykop biblijnych, np. „o czym opowiedział dzisiaj Jezus w przypowieści?”. Należy unikać stylu, który przypominałby szkolną rozmowę dydaktyczną, ponieważ to może blokować u dzieci samodzielne rozumienie Ewangelii, sugerując, że trzeba odpowiedzieć tak, jak oczekuje homilista. Innym sposobem rozpoczęcia dialogu może być użycie jakiegoś znaku lub słowa klucza, które pomoże złączyć treść Ewangelii z życiem codziennym² ${ }^{21}$. Segment drugi zawiera

20 Por. D. Sarzyńska, Strategie nadawcy $w$ dialogowanych kazaniach dla dzieci, w: Retoryka na ambonie, dz. cyt., s. 328.

${ }^{21}$ Hubert Łysy wskazuje, że właściwe obrazy i znaki pomagają pobudzić nie tylko rozum i wolę, ale także uczucia, realizując tym samym potrójny cel: egzegetyczno-poznawczy, wolitywny i uczuciowo-duchowy. Powołuje się przy tym na ks. Wolfganga Nastainczyka i Willego Hofsümmera. Pierwszy z nich dobiera znak odpowiedni do kerygmy, a drugi odwrotnie. Znakami są przedmioty i zjawiska, z którymi spotykają się słuchacze. Homilista pokazuje 
monolog homilisty, który może przyjąć następujące postaci: a) krótkie podsumowanie dokonanego dialogu, b) opowiadanie ilustrujące fragment biblijny, c) dłuższe podsumowanie - nauczanie na temat homilii. W krótkim podsumowaniu homilista zwraca uwagę na główną myśl homilii. Innym wariantem podsumowania jest propozycja podjęcia postanowienia lub wykonania zadania. W dłuższym podsumowaniu homilista wyjaśnia główne zagadnienia homilii i doprecyzowuje niejasne kwestie. Natomiast ilustracja czy exemplum mają obrazować treść słowa Bożego i dlatego muszą spełniać trzy retoryczne zasady: jasności, zwięzłości i wiarygodności. Opowiadanie jako przykład dla dzieci powinno być przedstawione barwnym językiem, odwoływać się do zmysłów wzroku i słuchu, zawierać formy osobowe czasowników w stronie czynnej, które dynamizują tekst ${ }^{22}$.

Według drugiej strategii nadawczej homilista rozpoczyna dialog odwołaniem się do czytań mszalnych, po którym od razu następuje odniesienie do życia albo odwrotnie - wychodząc od egzystencji ludzkiej, odnosi się do tekstu świętego i odkrywa ze słuchaczami Boże orędzie ${ }^{23}$. W tym kontekście warta uwagi jest propozycja Władysław Chaima, który poleca, aby homilista dokonał najpierw egzegezy tekstów biblijnych, a następnie zmotywował słuchaczy do rozmowy, przywołując np. prowokującą historię biblijną, inspirujący obraz lub sytuację życiową. Ten zabieg ma pobudzić do poszukiwań związku Ewangelii z życiem. Zaleca się, by dzieci mogły wyrazić swoje osobiste wnioski i przeżycia wobec całego zgromadzenia. Zadaniem homilisty jest zmotywowanie dzieci nieśmiałych i koncentrowanie na temacie rozkojarzonych. $\mathrm{W}$ trakcie

ich symboliczne znaczenie, a przez to pomaga odbiorcom dostrzec działanie Boga w świecie. Hubert Łysy słusznie zastrzega, że w tych wszystkich zabiegach „nieprzekraczalna granicą winno być zachowanie personalnego wymiaru chrześcijaństwa”, a stosowane „aktywizatory" mają koncentrować na osobowej relacji do Chrystusa. Przykładem sprzecznym z tą zasadą jest według autora obrazowanie grzechu wbijaniem i wyciąganiem gwoździ z krzyża, gdyż to nie oddaje zerwania i odnowienia relacji z Jezusem. Lepiej służą temu na przykład obrazy z życia rodzinnego. Por. H. Łysy, Liturgiczne i pozaliturgiczne przepowiadanie do dzieci w Kościele w Polsce po Soborze Watykańskim II. Teoria i praktyka, Opole 2011, s. 46. 58-59.

22 Por. D. Sarzyńska, Strategie nadawcy $w$ dialogowanych kazaniach dla dzieci, dz. cyt., s. 331-336.

${ }^{23}$ Por. D. Sarzyńska, Strategie nadawcy w dialogowanych kazaniach, dz. cyt., s. 337. 
rozmowy może nastąpić również chwila milczenia, której nie należy się bać, ale nie trzeba jej też sztucznie przedłużać. Na zakończenie homilista konkluduje dialog, artykułując, co Bóg przekazuje słuchaczom. Jeśli uczestnicy homilii sami rozpoznali, wyrazili i zaakceptowali słowo Boże do nich skierowane, to prowadzący krótko podkreśla najważniejsze sprawy i może poprowadzić modlitwę dziękczynienia i uwielbienia Boga za Jego działanie ${ }^{24}$.

Trzeci typ strategii nadawczej w dialogu homilijnym to przywołanie osoby trzeciej w roli świadka, eksperta lub gościa zaproszonego do wywiadu. Ta osoba może przyjąć rolę postaci biblijnej ${ }^{25}$. Forma ta będzie szczególnie atrakcyjna dla dzieci, jeśli zaproszona osoba wejdzie z nimi $\mathrm{w}$ interakcję, a nawet poprosi o pomoc, np. w odpowiedzi na pytania homilisty. Jeżeli wywiad ma być formą dialogu homilijnego, to prowadzi go sam homilista podczas homilii lub przywołuje treść wcześniej przeprowadzonego wywiadu.

Ciekawe i owocne, zwłaszcza w przypadku dzieci starszych, śmiałych i przyzwyczajonych do rozmowy, mogą być tzw. „echa słowa”, którym posługują się wspólnoty neokatechumenalne. Są to spontaniczne refleksje uczestników po czytaniach biblijnych - o tym, jak słowo Boże ich poruszyło, co było dla nich ważne, co zrozumieli, z czym mają trudność itp. Przepowiadający zaś odnosi się do poruszonych przez nich problemów i potrzeb słuchaczy ${ }^{26}$. Metodą przypominającą „echo słowa” jest proponowany przez Chaima tzw. „mały krąg”. W tym przypadku homilista zadaje uczestnikom konkretne pytania dotyczące tekstu biblijnego, a następnie wsłuchuje się w każdą wypowiedź. Proponowane pytania mogą być następujące: „Co w tekście jest dla mnie ważne?”, „Co ważne jest dla wszystkich?" Należy przy tym wystrzegać się wypowiedzi ogólnych, teoretyzujących i moralizujących.

Podobną propozycją ze strony Gerarda Siwka są dopowiedzenia, określane jako „homilia uzupełniana”. Polega ona na wypowiedzeniu przez

24 Por. W. Chaim, Rozmowa w przekazie kaznodziejskim, dz. cyt., s. 316-319.

25 Por. D. Sarzyńska, Strategie nadawcy $w$ dialogowanych kazaniach, dz. cyt., s. 338.

26 Statut Drogi Neokatechumenalnej, art. $11 \S 2$, http://www.camminoneocatecumenale.it/public/file/pl_Statut_2008-05-11.pdf (09.03.2017). 
uczestników osobistych refleksji do wysłuchanej homilii. Nie są to jednakże pytania do homilisty. Ta forma jest bardzo ryzykowna, ponieważ słuchacze mogą po homilii pozostać z indywidualnymi i subiektywnymi refleksjami innych uczestników zamiast ze słowem Bożym. W takiej sytuacji homilista jest odpowiedzialny, by dostatecznie i ostatecznie wybrzmiało słowo Boże.

Jak widać, dialog realny może odbywać się na różne sposoby. Podkreślić w nim należy zasadniczą i niezastąpioną rolę homilisty, który wprowadza w dialog realny, przewodniczy mu i go kończy. W tym celu moderujący może wprost oznajmić, że czas zakończyć dialog, może też zabrać głos i podsumować rozmowę. Innym sposobem jest podziękowanie Bogu za jego słowo i działanie Ducha Świętego. Ważne byłoby też wezwanie do podjęcia konkretnych postanowień wynikających z usłyszanego orędzia zbawczego. Czytelnym zakończeniem dialogu homilijnego jest zachęta, aby przejść do liturgii eucharystycznej. Wacław Świerzawski sugeruje wyjść w homilii od bieżącej sytuacji egzystencjalnej słuchaczy, konkretnej społeczności lub powszechnie znanej ludziom albo od wydarzenia liturgicznego, a zakończyć ją nawiązaniem do celebrowanego misterium liturgicznego ${ }^{27}$.

Każdy przepowiadający zatroskany o to, aby słowo Boże wybrzmiało jasno i skutecznie, poszukuje z pewnością różnych form przekazu orędzia zbawczego. $\mathrm{Z}$ różnych metod ożywienia dialogu z dziećmi należy korzystać umiejętnie, aby nie niszczyć charakteru liturgii. W dialogu homilijnym należy unikać takich metod, które deprecjonują rolę homilisty jako moderatora dialogu homilijnego. Należy też unikać aplikowania do homilii katechetycznych metod aktywizujących, które są atrakcyjne, ale pasują bardziej do katechezy niż liturgii. Ich stosowanie może wywoływać wrażenie, że homilia jest pewnego rodzaju przerwą na dyskusję podczas liturgii, niczym przerwa na reklamę w trakcie interesującego filmu. Papież Franciszek przypomina, że „homilia nie może być rozrywkowym spektaklem, nie odpowiada logice przekazów medialnych, ale powinna wzbudzić zapał i nadać sens celebracji” (EG 138). Adam

27 Por. W. Świerzawski, Misterium Christi. Chrystus obecny w liturgii i życie chrześcijańskie, Kraków 1975, s. 250-252. 
Kalbarczyk zauważył, że zabiegi dramatyzujące lub obrazujące homilię, takie jak np.: formy teatralne, obrazy, rekwizyty, mają służyć jako forma przekazu słowa Bożego, nie zaś tworzyć oderwane od liturgii widowisko, show ${ }^{28}$. Formy te są dopuszczalne, o ile służą „wewnętrznemu celowi liturgii”. Dlatego stosując je, trzeba zachować wielką roztropność i wyczucie. Joseph Ratzinger stwierdził: „Liturgia może przyciągać ludzi tylko wówczas, gdy nie spogląda na samą siebie, lecz na Boga, gdy pozwala Mu wejść w siebie i działać” ${ }^{29}$. Hubert Łysy przypomniał, że urozmaicona forma przepowiadania, zwłaszcza do dzieci, powinna zawsze służyć treści. Celem bowiem przepowiadania jest „zbawić”, a nie tylko „zabawić”30.

Osobną, bardzo ważną kwestią formalną dialogu homilijnego jest język. W niniejszym artykule dość wspomnieć, że powinny go cechować: egzystencjalność, konkretność, obrazowość, przejrzystość logiczna, poprawność językowa, prostota i pozytywne brzmienie ${ }^{31}$. W sprzeczności z dialogicznym wymiarem homilii i dialogiczną funkcją języka są więc: żargon teologiczny, styl oficjalny, abstrakcyjność pojęciowa zamiast konkretu egzystencjalnego, nielogiczność i niepoprawność językowa (słowotok), a także apodyktyczność. Głównym zaś powodem niekomunikatywności języka przepowiadania, jak się zdaje, jest oderwanie od egzystencjalnych doświadczeń słuchaczy ${ }^{32}$. Język wszakże ma służyć

28 Por. A. Kalbarczyk, Teatr animacji jako medium słowa Bożego. Studium teatralno-homiletyczne, Poznań 2013, s. 268-269. Autor omówił również praktykę niektórych homilistów posługujących się podczas przepowiadania do dzieci lalką pacynką. Jak zauważył, może ona pełnić rolę współrozmówcy z homilistą. Wówczas będzie odgrywany dialog, który wcześniej wyreżyseruje przepowiadający. Ta „ożywiona lalka jest obrazem człowieka wchodzącego w dialog z żywym słowem Bożym”. Dlatego dialog z pacynką powinien być dialogiem wirtualnym ze słuchaczami homilii. Głoszący musi uwzględniać słowo Boże i życie słuchaczy. Dialogi z pacynką mają być „z życia wzięte”. Przywołany autor zauważa przy tym ryzyko zastępowania homilii katechezą i pomieszania ról, gdy na przykład homilista odgrywa lalką rolę Pana Jezusa. W związku z tym poleca, aby tak konstruować homilię, żeby kwestie wypowiadane przez lalkę nie dominowały nad przepowiadaniem homilisty, nie były zbyt ludyczne i komiczne. Ponadto tę swoistą inscenizację należy stosować tylko co jakiś czas. Por. A. Kalbarczyk, Teatr animacji jako medium słowa Bożego..., dz. cyt., s. 281-285.

${ }^{29}$ J. Ratzinger, Duch liturgii, Poznań 2002, s. 176.

30 H. Łysy, Liturgiczne i pozaliturgiczne przepowiadanie do dzieci, s. 43-47.

31 H. Sławiński, Język współczesnego przekazu Ewangelii..., s. 61.

32 Por. B. Matuszczak, Kilka uwag o przejawach niekomunikatywności języka współczesnych kazań, w: Język polski, t. 4, red. W. Książek-Bryłowa, H. Duda, Lublin [brw], s. 63-70. 
komunikowaniu się ze słuchaczami, a nie prezentowaniu elokwencji i wiedzy mówiącego.

\section{Treść dialogu homilijnego}

Podejmując dialog z dziećmi podczas homilii, trzeba trafnie określić jego treść. Po pierwsze należy, na gruncie homiletyki materialnej, poczynić rozróżnienie na treść przepowiadania homilijnego i treść dialogu homilijnego. Najprościej rzecz biorąc, ta pierwsza dotyczy orędzia zbawczego, jakie komunikuje Bóg człowiekowi. Druga związana jest z życiem uczestników zgromadzenia liturgicznego. W dialogu bowiem wszyscy uczestnicy komunikują sobie informacje a ponadto samych siebie, swoje myśli i przeżycia. Treść dialogu homilijnego może więc być szersza niż przepowiadania, ale to przesłanie ewangeliczne jest pierwszorzędnym przedmiotem dialogu. W homilii z udziałem dzieci ich spostrzeżenia, doświadczenia, przeżycia są niejako współczesnym kontekstem głoszonego słowa Bożego. Należy je uwzględniać i naświetlać prawdą Ewangelii.

Po drugie należy rozróżnić źródło i tworzywo homilii. Homilia ma bowiem charakter teandryczny. Jest słowem Bożym w postaci słowa ludzkiego, gdyż „Odwieczne Słowo przyjmuje ziemski sposób bytowania w słowie ludzkim" ${ }^{33}$. Soborowa konstytucja o liturgii wskazuje, że swoją treść homilia powinna „czerpać przede wszystkim ze źródeł Pisma Świętego i liturgii, jako zwiastowanie przedziwnych dzieł Bożych w dziejach zbawienia, czyli w misterium Chrystusowym, które zawsze jest w nas obecne i działa, zwłaszcza w obrzędach liturgicznych" (KL 35). Podobnie instrukcja Inter oecumenici rozumie homilię jako „wyjaśnienie albo jakiegoś aspektu czytań Pisma Świętego, ewentualnie innego tekstu z części stałych lub własnych mszy świętych z dnia, uwzględniając czy to czczoną tajemnicę, czy szczególne potrzeby słuchaczy" (IO 54). Tak więc ważne jest, aby homilista zwiastował słowo i działanie Boże dzieciom w kontekście ich życia, codziennych przeżyć, radości czy lęków.

33 W. Przyczyna, Kazanie jako słowo Boże, w: Fenomen kazania, red. W. Przyczyna, Kraków 1994, s. 64. 
Tworzywem homilii mogą więc być różne opowiadania, teksty religijne pozaliturgiczne, literatura, fragmenty prasy, piosenek czy inne, ale powinny być one wykorzystane dosłownie jako tworzywo przepowiadania homilisty, w którym zawarte będzie słowo Boże. W tym miejscu warto zwrócić uwagę, że stosowane przez niektórych głoszących opowiadania nie mogą same w sobie zastąpić Biblii, ale winny być jej ilustracją albo wywoływać obrazy ułatwiające zrozumienie przesłania Ewangelii. Dzieci uczestniczące w liturgii poprzez dialog homilijny mają się zwrócić do Pana Jezusa, a nie bohatera opowiadania czy choćby samego homilisty. Inaczej dzieci wysłuchają bajki o Ewangelii, w której ewentualnie wystąpił Pan Jezus, zamiast Dobrej Nowiny o Jezusie. Warto więc, aby każdy homilista zastanowił się, czy przepowiadając podczas liturgii z udziałem dzieci, skupił się na ich zabawieniu, czy ich zbawieniu.

Podsumowując powyższe rozważania na temat dialogu homilijnego podczas zgromadzeń liturgicznych z udziałem dzieci, można pod adresem homilistów skierować następujące wnioski. Przede wszystkim należy uświadomić sobie, że homilia jest aktem liturgicznym i jako taka jest dialogiem między zgromadzeniem i Bogiem, który inicjuje i moderuje homilista. Oznacza to, że homilia winna wyrażać orędzie zbawcze i potrzeby dzieci w świetle słowa Bożego, a ponadto wprowadzać je do czynnego uczestnictwa w liturgii. Dialog sprzyja bardziej refleksyjnemu i osobistemu przyjmowaniu słowa Bożego, a więc także kształtowaniu dojrzalszej wiary. Najpierw jednak sam homilista musi kształtować w sobie dialogiczną postawę wobec słuchaczy. W związku z tym musi on uważnie wsłuchać się w słowo Boże i życiowe sprawy dzieci, aby jako nauczyciel wszedł w świat dziecięcych przeżyć, a jako mistagog wprowadził je do rozmowy $z$ Jezusem w liturgii. W tym celu może prowadzić w homilii dialog wirtualny i różne formy dialogu realnego. Pamiętać przy tym powinien, że chociaż treść dialogu homilijnego może objąć różne sprawy dzieci, to pierwszorzędnym przesłaniem homilii z udziałem dzieci musi być Ewangelia. 


\section{Summary}

\section{Homilia z udziałem dzieci}

Artykuł przedstawia zagadnienie dialogu $\mathrm{w}$ homilii $\mathrm{z}$ udziałem dzieci. Na płaszczyźnie homiletyki fundamentalnej zdecydowanie podkreśla liturgiczną naturę homilii i jej organiczny związek $\mathrm{z}$ celebrowaną liturgią. W nawiązaniu do etymologii źródłosłowu greckiego przedstawia homilię jako dialog Boga ze zgromadzeniem liturgicznym, który prowadzi homilista. W ten sposób wskazuje, że jest ona raczej dynamicznym wydarzeniem niż statycznym pouczeniem. Dialog jest jej fundamentalną zasadą wewnętrzną. Opisane zostały więc dwa rodzaje dialogu homilijnego między przepowiadającym i słuchaczami - wirtualny i realny z licznymi sposobami ich realizacji. Celem homilii z udziałem dzieci jest ostatecznie wprowadzenie ich do dialogu z Jezusem w liturgii, w rzeczywistość zbawczą, nie zaś zabawienie poprzez różne metody aktywizujące. Treścią zaś dialogu homilijnego mogą być sprawy i przeżycia dziecięce, ale zawsze dostatecznie wyraźnie musi wybrzmieć treść orędzia zbawczego.

Słowa kluczowe: dialog, dzieci, homilia, liturgia

\section{Homily with Children}

The article presents a dialogue in a homily with children. On the level of fundamental homiletics, it strongly emphasizes the liturgical nature of the homily and its organic relationship with the celebrated liturgy. In reference to the etymology of the Greek rootline, it presents a homily as God's dialogue with the liturgical assembly is led by a homilist. In this way, he indicates that it is rather a dynamic event than a static instruction. The dialogue is its fundamental internal principle. Thus, two kinds of homily dialogue between the homilist and the listeners have been described - virtual and real with numerous ways of implementing them. The goal of a homily with children is ultimately introducing them into a dialogue with Jesus in the liturgy and into a salvific reality, not by entertaining them through various activating methods. The content of the homily dialogue may be children's matters and experiences but the content of the message of salvation must always be clearly visible.

Keywords: dialogue, children, homily, liturgy 


\section{Bibliografia}

Benedykt XVI, Adhortacja apostolska Sacramentum Caritatis.

Chaim W., Rozmowa w przekazie kaznodziejskim, w: Retoryka na ambonie, red. P. Urbański, Kraków 2003, s. 291-325.

Dyk S., Homilia jako integralna część liturgii eucharystycznej, „Zeszyty Naukowe KUL” 48 (2005) 3/191, s. 59-69.

Głowa W., Homilia jako forma liturgicznego przepowiadania, „Roczniki Teologiczne” 50 (2003) 8, s. 179-198.

Grasso D., La predicazione alla comunitá cristiana, Roma 1969.

Jan Paweł II, Kodeks Prawa Kanonicznego, Poznań 1984.

Kalbarczyk A., Teatr animacji jako medium stowa Bożego. Studium teatralno-homiletyczne, Poznań 2013.

Kongregacja do spraw Biskupów, Dyrektorium Eccelsiae imago de pastorali ministerio episcopoum (22.02.1973), „Enchiridion Vaticanum” 4 (1971-1973), n. 1945-2328.

Kongregacja do spraw Kultu Bożego i Dyscypliny Sakramentów, Dyrektorium homiletyczne, tłum. P. Borkowski, Poznań 2015.

Kongregacja do spraw Kultu Bożego, Dyrektorium o Mszach św. z udziałem dzieci, Pueros Baptizatos (01.11. 1973).

Kongregacja ds. Kultu Bożego i Dyscypliny Sakramentów, Instrukcja o niektórych aspektach dotyczących współpracy wiernych świeckich w ministerialnej posłudze kapłanów Ecclesia de Misterium (1997), „Acta Apostolicae Sedis” 89 (1997), s. 852-877.

Kongregacja Kultu Bożego i Dyscypliny Sakramentów, Nowe Ogólne Wprowadzenie do Mszału Rzymskiego (2002), Poznań 2004.

Kuc L., Praktyka przepowiadania słowa Bożego. Materiały do nauczania w zakładach teologicznych, t. 2, Warszawa 1973.

Lewek A., Problem dialogu w kaznodziejstwie, „Biblioteka Kaznodziejska” 87 (1971) 2-3, s. 137-141.

Łysy H., Liturgiczne i pozaliturgiczne przepowiadanie do dzieci w Kościele w Polsce po Soborze Watykańskim II. Teoria i praktyka, Opole 2011.

Panuś K., Historia kaznodziejstwa, Kraków 2007.

Przyczyna W., Kazanie jako słowo Boże, w: Fenomen kazania, red. G. Siwek, Kraków 1994, s. 48-66.

Przyczyna W., Przepowiadanie w liturgii. Cechy posoborowej homilii, „Ateneum Kapłańskie" 521 (1996), s. 179-187.

Ratzinger J., Duch liturgii, przeł. E. Pieciul, Poznań 2002.

Rostworowski S., Czy naprawdę kazanie dialogowe?, „Homo Dei” 38 (1969) 3, s. 223-224.

Sarzyńska D., Strategie nadawcy $w$ dialogowanych kazaniach dla dzieci, w: Retoryka na ambonie, red. P. Urbański, Kraków 2003, s. 327-339.

Siwek G., Dialog w głoszeniu słowa Bożego, „Biblioteka Kaznodziejska” 2/151 (2007) 3-4, s. 9-17. 
Sławiński H., Między ciagłościa a zmianą. Teoria homilii w Stanach Zjednoczonych po II soborze watykańskim, Kraków 2008.

Sobieraj E., Homilia w Katolickiej teologii posoborowej, w: Eucharystia w duszpasterstwie, red. A. L. Szafrański, Lublin 1977, s. 167-253.

Stanček L., Kňaz rétor, Spišské Podhradie 2001.

Statut Drogi Neokatechumenalnej, http://www.camminoneocatecumenale.it/public/file/pl_Statut_2008-05-11.pdf (09.03.2017).

Stewart J., Mosty zamiast murów. Podręcznik komunikacji interpersonalnej, tłum. J. Suchecki i in., Warszawa 2008.

Świerzawski W., Misterium Christi. Chrystus obecny w liturgii i życie chrześcijańskie, Kraków 1975.

Święta Kongregacja Kultu Bożego, „Notitiae” Cittá del Vaticano, 83 (1973) 9.

Święta Kongregacja Kultu Bożego, Wprowadzenie do drugiego wydania lekcjonarza mszalnego (1981), w: Lekcjonarz mszalny, t. 1,wyd. 2, Poznań 2015.

Wal J., Dialog, w: Leksykon teologii pastoralnej, red. R. Kamiński, W. Przygoda, M. Fijałkowski, Lublin [brw], s. 175-181.

Wal J., Vademecum dialogu, Kraków 1998. 